Brit. F. vener. Dis. (1970) 46, 114

\title{
Physician reporting of venereal disease in the USA
}

\author{
J. S. MCKENZIE-POLLOCK \\ Director, Venereal Disease Division, American Social Health Association
}

IT is not intended to discuss here the pros and cons of compulsory reporting of cases of venereal disease treated by physicians in private practice. In all the fifty States in the USA the reporting of cases of venereal disease is compulsory by law. It is appreciated that the physician finds himself in a dilemma when confronted with the duty of compulsory reporting. In 1962 a survey was conducted to determine the number of cases of venereal disease treated by private physicians. This survey was repeated in 1968 , and it is the findings of this latter survey which I propose to summarize.

\section{Purpose of the survey}

This was to determine the number of cases of infectious syphilis, other syphilis, and gonorrhoea treated by all medical and osteopathic physicians in private practice in the United States from April 1 to June 30, 1968.

This information, together with the number of cases reported as treated by public health clinics and other public institutions, provides a truer picture of the actual incidence of venereal disease in the United States than is at present available. It also provides more accurate information on the actual incidence in each state and major city.

With the availability of this information on the incidence of infectious syphilis and gonorrhoea, public health authorities-national, state, and local-can plan programmes to cope with the venereal disease problem according to its true dimensions.

\section{Survey method}

All medical and osteopathic physicians in private practice in the United States were requested by letter, addressed to them individually, to reply to the questionnaire shown below.

Letters were mailed in time to reach all physicians by July 1, 1968. A follow-up letter was mailed in midAugust to all physicians who had not responded to the initial mailing by that time.

Mailing lists were compiled from lists maintained by the American Medical Association and the American Osteopathic Association for all physicians in private practice, including full-time medical school faculty. The 'private physician' classification used for these mailings excluded physicians in federal service, interns, residents, and fellows, full-time staff in hospital service, and physicians in administrative medicine, research, and retirement.

The questionnaire was sent to 206,283 medical and osteopathic physicians in private practice in the United States and Puerto Rico, and 134,633 (65.3 per cent. of those approached) responded.

\section{Physician Code Number ..........}

How many new (to you) cases of diagnosed syphilis and/or gonorrhoea (excluding cases previously treated for these infections and persons treated 'prophylactically') did you treat in your private practice during the 3-month period, April 1 to June 30, 1968? (Do not include public cases treated by you in health clinics, hospital wards, or military facilities.)

INFECTIOUS SYPHILIS . . . . . . . . . . . . . . . . NUMBER OF CASES TREATED Primary syphilis (chancre present or healing) and/or secondary syphilis (generalized manifestations of skin, mucosae, etc., occurring in the first few years of the disease but not including late manifestations).

OTHER STAGES OF SYPHILIS $\ldots \ldots \ldots \ldots \ldots \ldots \ldots \ldots \ldots$ NUMBER OF CASES TREATED $\ldots \ldots \ldots \ldots$ Positive serology (excluding known 'false positives') only, late manifestations, or congenital manifestations. 


\section{Findings}

43,720 physicians ( 32.5 per cent. of those responding) reported that they had treated one or more cases of infectious syphilis, other syphilis, or gonorrhoea during the 3-month period.

$$
\begin{aligned}
& \text { 4,370 physicians ( } 3 \cdot 2 \text { per cent. of those responding) } \\
& \text { treated } \\
& 8,849 \text { cases of infectious syphilis. } \\
& 10,934 \text { physicians }(8 \cdot 1 \text { per cent. of those responding) } \\
& \text { treated } \\
& 22,022 \text { cases of 'other' syphilis. } \\
& 39,392 \text { physicians }(29 \cdot 3 \text { per cent. of those responding) } \\
& \text { treated } \\
& 185,548 \text { cases of gonorrhoea. }
\end{aligned}
$$

\section{Cases reported as percentage of cases treated} INFECTIOUS SYPHILIS

The total number of cases of infectious syphilis reported to public health authorities by all physicians in private practice during the 3-month period of the survey was 1,655 . The 134,633 physicians responding to the survey, representing $65 \cdot 3$ per cent. of all physicians in private practice, stated that they had treated 8,849 cases during this same period. Assuming that the 34.7 per cent. who did not respond treated cases at the same rate as the 65.3 per cent. who responded, 206,283 physicians would have treated 13,744 cases of infectious syphilis during the quarter. The total number of cases reported to public health authorities by all physicians thus represents only 12 per cent. of the cases assumed to have been treated by the 206,283 physicians queried.

\section{'OTHER' SYPHILIS}

The total number of cases of 'other' syphilis reported to public health authorities by all private physicians during the 3-month period was 11,277 , but the 65.3 per cent. who responded had treated 22,022 cases. Again assuming that the 34.7 per cent. of nonrespondents treated cases at the same rate as the $65 \cdot 3$ per cent. of respondents, 206,283 physicians would have treated 34,113 cases of 'other' syphilis during the quarter. The total number of cases reported by all physicians to public health authorities thus represents 33.1 per cent. of the cases assumed to have been treated by the 206,283 physicians queried.

\section{GONORRHOEA}

The total number of cases of gonorrhoea reported to the public health authorities by all private physicians during the period was 31,378 . The $65 \cdot 3$ per cent. responding had treated 185,548 cases. Again assuming that the 34.7 per cent. of non-respondents treated cases at the same rate as the 65.3 per cent. of respondents, 206,283 physicians would have treated
288,054 cases of gonorrhoea during the quarter. The total number of cases reported by all physicians to public health authorities represents only 10.9 per cent. of those assumed to have been treated by the 206,283 physicians queried.

\section{Projection of findings to fiscal year 1968}

\begin{tabular}{|c|c|c|c|}
\hline No. of cases & $\begin{array}{l}\text { Infectious } \\
\text { syphilis }\end{array}$ & $\begin{array}{l}\text { 'Other' } \\
\text { syphilis }\end{array}$ & Gonorrhoea \\
\hline $\begin{array}{l}\text { Treated and reported by } \\
\text { public sources } \\
\text { Treated and reported by } \\
\text { private physicians } \\
\text { Treated but not reported } \\
\text { by private physicians } \\
\text { (total estimated treated } \\
\text { less total reported) }\end{array}$ & $\begin{array}{r}12,953 \\
7,229\end{array}$ & $\begin{array}{l}32,714 \\
45,299\end{array}$ & $\begin{array}{l}307,624 \\
123,756\end{array}$ \\
\hline $\begin{array}{l}\text { Estimated total treated } \\
\text { by all sources during } \\
\text { fiscal year } 1968\end{array}$ & 75,207 & 171,944 & $1,449,581$ \\
\hline
\end{tabular}

Projecting the number of cases in each category estimated as treated by all private physicians during the quarter to the entire fiscal year, July 1, 1967, to June 30,1968 , and adding to this projection the number of cases in each category treated and reported by public sources for the same period, produces the following estimates of actual incidence by category for the fiscal year 1968:

\section{Comparison of 1968 and 1962 surveys}

A similar national survey of the incidence of venereal disease was conducted by the American Social Health Association in 1962 for the same quarterly period, with the same sponsors as in 1968 and also financed by a contract with the Public Health Service. In 1962 computation of the average rate of reporting was based solely on applying the number of cases treated by the 71.7 per cent. of responding physicians to the number of cases reported to public health authorities by all physicians. It did not include a projection of the estimated number of cases treated by the 28.3 per cent. of non-respondents.

In order that a reasonable comparison could be made between the findings of the two surveys, the 1968 survey was computed both on the basis of an estimated rate of reporting for all private physicians, had they responded, and on the basis of responding physicians only, as in 1962 . It was also possible to recalculate the overall results of the 1962 survey to obtain a national average of reporting for the quarter based on an estimated rate for all private physicians, had they responded.

Comparison of the findings, based on both the 1962 method of computation (excluding non-respondents) and the 1968 method (including a projection for non- 
respondents) shows improvement in private physician reporting as follows:

\begin{tabular}{|c|c|c|c|}
\hline \multirow{2}{*}{\multicolumn{2}{|c|}{ Percentage of Reporting }} & \multicolumn{2}{|c|}{ Fiscal year } \\
\hline & & \multirow{2}{*}{$\begin{array}{l}1962 \\
11.3 \\
37.5 \\
10 \cdot 8\end{array}$} & \multirow{2}{*}{$\begin{array}{c}1968 \\
18.7 \\
51.2 \\
16.9\end{array}$} \\
\hline $\begin{array}{l}\text { Computed by } \\
1962 \text { method }\end{array}$ & $\begin{array}{l}\text { Infectious syphilis } \\
\text { 'Other' syphilis } \\
\text { Gonorrhoea }\end{array}$ & & \\
\hline $\begin{array}{l}\text { Computed by } \\
1968 \text { method }\end{array}$ & $\begin{array}{l}\text { Infectious syphilis } \\
\text { 'Other' syphilis } \\
\text { Gonorrhoea }\end{array}$ & $\begin{array}{r}8 \cdot 1 \\
26 \cdot 9 \\
7 \cdot 7\end{array}$ & $\begin{array}{l}12 \cdot 0 \\
33 \cdot 1 \\
10 \cdot 9\end{array}$ \\
\hline
\end{tabular}

Comparison of the total number of cases of infectious syphilis and gonorrhoea estimated as treated during fiscal year 1962 with the number estimated as treated during fiscal year 1968, calculated by adding the number of cases reported by public sources to the number of cases estimated as treated by all private physicians (including a projection for nonrespondents) shows the following changes in total incidence in the two fiscal years:

\begin{tabular}{llll}
\hline Fiscal year & $\begin{array}{l}\text { Infectious } \\
\text { syphilis }\end{array}$ & Gonorrhoea \\
\cline { 2 - 3 } 1962 & $\begin{array}{ll}106,442 \\
1968\end{array}$ & 75,207 & $1,071,125$ \\
\cline { 2 - 3 } & $-31,235$ & & $1,449,581$ \\
\hline
\end{tabular}

The reduction in infectious syphilis supports the forecast of public health authorities that continued application of the case-finding process-identification and treatment of all sexual contacts of all persons with infectious syphilis-will progressively reduce its incidence.

The survey also supports the estimates of public health officials that the number of cases of gonorrhoea in the United States has reached epidemic proportions. The survey estimate that $1,500,000$ gonorrhoea cases were treated in 1968 also underlines the need for vigorous planning and major increases in financial support for gonorrhoea control programmes.

Urologists and general practitioners are the physicians who are most likely to treat venereal disease in private practice.

Obstetricians and gynaecologists, osteopaths, internal medicine specialists, dermatologists, specialists in preventive medicine, and gastroenterologists in that order, also treated a significant number of cases.

The survey findings have been published by the American Social Health Association and by each of the sponsoring organizations.

\section{Summary}

Four out of every five cases of venereal diseases in the United States of America are treated by physicians in private practice. They report to the public health authority only one out of every nine cases they treat.

This survey shows how a voluntary agency, in this case the American Social Health Association, can perform a useful service in acting as a link between public health and the private practice of medicine.

\section{La déclaration des maladies vénériennes par les médecins, aux Etats-Unis d'Amerique}

\section{SOMMAIRE}

Quatre sur 5 des cas de maladies vénériennes aux U.S.A. sont traités par les médecins en clientèle privée. Ceux-ci déclarent à l'autorite sanitaire seulement 1 sur 9 des cas qu'ils traitent.

Cette enquête montre combien une organisation volontaire-dans le cas présent l'American Social Health Association-peut remplir un rôle utile en agissant comme lien entre les services de santé publique et la médecine privée. 